\title{
A Study on the Cultural Exchange between South and North Korea in the Unification Era with Focus on Performance Arts as Cultural Content
}

\author{
Cheul Choi ${ }^{1}$, Sang Yun Jeong ${ }^{2}$ \\ ${ }^{1}$ Doctor of Culture, Graduate School of Chosun University, South Korea, eltorechoi@ hanmail.net \\ ${ }^{2}$ Ph.D. in the Department of Culture at Chosun University, South Korea, Art8633@naver.com
}

Corresponding author: Cheul Choi

\begin{abstract}
Culture refers to the people's way of life. Even if people from the two Koreas use the same language as Koreans, they have not had mutual exchanges for a certain period or have lived toward different political ideologies and various patterns of life. This can be seen by looking into the field of cultural and artistic exchanges. In order to overcome this heterogeneity and prepare for the era of unification, more active exchanges between north and south Korea are needed, and the discovery and development of content that must be used and developed together beyond just exchanges are urgently needed. It is necessary to establish an altruistic relationship between north and southKorea, which are preparing for the era of reunification, and it is imperative that north and south Korea to collaboratively study and develop content for the exchanges.

For this reason, this study analyzed contents of the performances of the North and South in the previous exchanges. The result showed the need to develop contents that can be shared beyond the exchange of exhibitionistic culture and art to create a diplomatic atmosphere. This research aims to play a significant role in bringing together the Korean people in the era of unification under the principle of mutual benefit between the two Koreas. In addition, problems and solutions can be found through this study by examining the situation of inter-Korean cultural exchanges, policies for promoting civilian exchanges, and common cultural contents between the two Koreas.
\end{abstract}

Keywords: Cultural Contents, South Korea, North Korea, Unification

\section{Introduction}

The rapidly changing situation, the chaotic era, and the hopeless situation on the Korean Peninsula have a profound impact on our overall lives, including economic diplomacy. The Korean Peninsula is becoming the center of the diplomatic wars of powerful nations and a battleground for their endless pursuit of interests. How should Korea address this dilemma? Write in a separate sentence. Consider the following: Russia and China compete to hold influence through the North's nuclear development while the South is caught between the complex inter-Korean and the U.S. and other Western nations diplomatic relationships.

The economic leap and prosperity of the Republic of Korea will be a dialogue through restoring trust in inter-Korean relations. Moon Jae-in, who took power after the impeachment of and the government's revolution against Park Geun-hye, launched the government's successful first of the inter-Korean talks in 2018, 9 a.m. on April 27 (Korea), Panmunjeom. It lasted for 29 minutes. The second summit was held

Received: November 16, 2020; $1^{\text {st }}$ Review Result: January 07, 2021; $2^{\text {nd }}$ Review Result: February 19, 2021 Accepted: March 29, 2021 
secretly on the spot at Tongilgak in the northern section of the Panmunjom Joint Security Area on May $26,2018$.

The third, and probably the most challengeing, inter-Korean summit was on September 20 to 18, 2018, Democratic People's Republic of Korea (Moon Jae-in regime has been held in Pyeongyang in the first to third and older. Kim Dae-jung administration in primary, Roh Moo-hyun administration) that there was a second summit.

Although there was an atmosphere of reconciliation and coordination to create a successful U.S.North Korea talks, our bridge role for the U.S.-North Korea negotiations, which can be seen as the final destination, was limited. It is difficult to reach an agreement and exchange in earnest under U.N. sanctions on North Korea.

Nevertheless, there should be dialogue and exchanges for peaceful coexistence, and the real area of such exchanges is the social and cultural sectors with low U.N. sanctions on North Korea and people's negative perceptions.

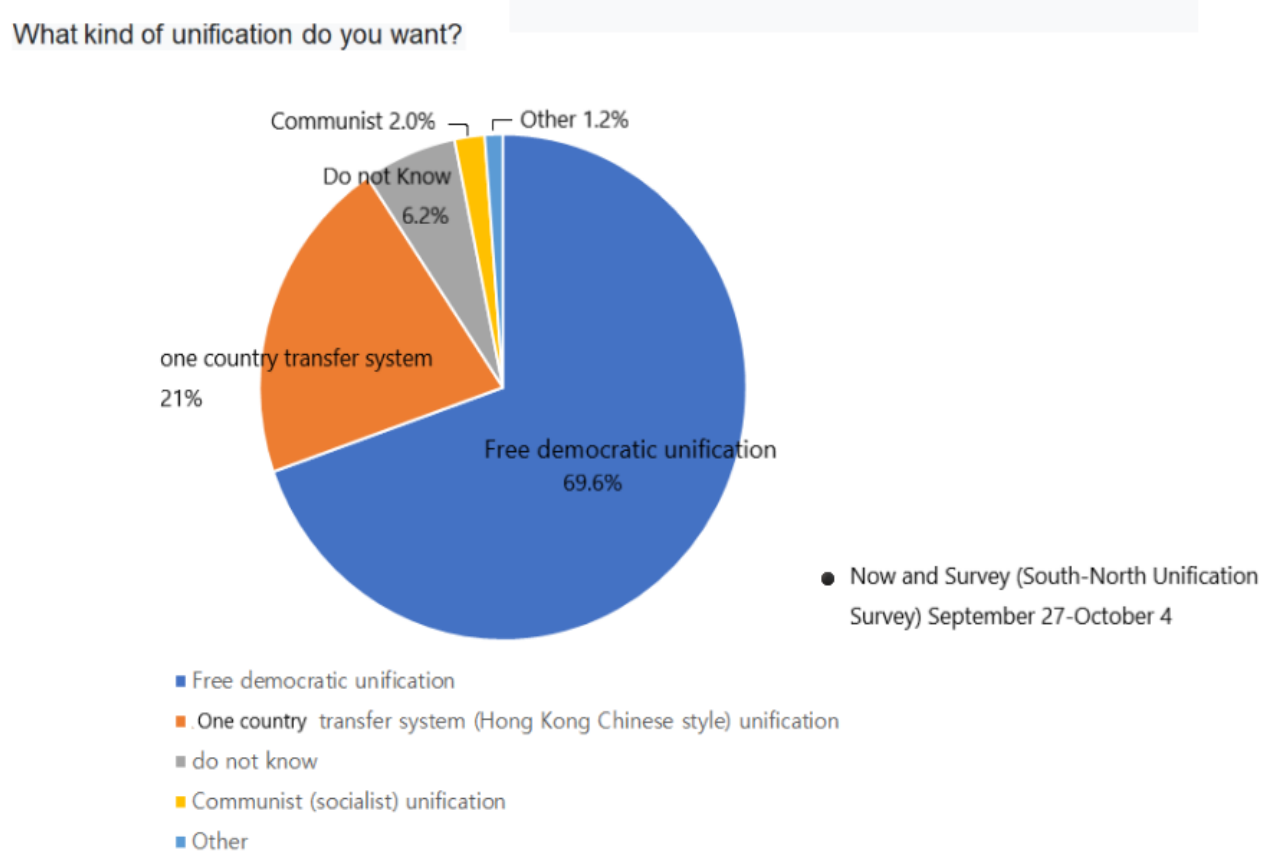

[Fig. 1] Now \& Survey(South-North Unification Survey) September 27-Octerber 4, 2018

In the era of unification, north and south Korean relations and dialogue on North Korea and the U.S. are at the center of the talk. Elimnet Now \& Survey conducted a survey on the people's support for peaceful unification as the impetus of the inter-Korean Summit from September 27 to October 4, 2018.The survey respondents were a total of 500-271 males and 229 females in their 10 s to $60 \mathrm{~s}$, with a $95 \%$ confidence level and a sample error of \pm 4.38 percentage points. When asked about the idea of reunification, more than three-quarters of the respondents $(76.6 \%)$ said they wanted unification, and $23.4 \%$ said they did not want unification, Like the previous survey indicating that the opinion that they wanted unification between the two Koreas was overwhelming. (http://www.kswnews.com/news/articleView.html?idxno=3837)[1]. It is an aspiration and the creation of this atmosphere will continue to gain momentum through cultural exchanges.

It can also be said that the most necessary thing in an era when the identity of the Korean people is challenged amid the difficult diplomatic landscape after becoming a divided country for more than half a century is to restore homogeneity, and cultural exchanges are essential for us to prepare for the era of 
reunification. For example, we can see by looking at the unification process of Germany, a divided country. Negotiations for the signing of a cultural agreement began in November 1973, but 13 years later, in May 1986, the cultural agreement was signed, and exchanges in the cultural sector began later than in other fields. This is because unlike economic and humanitarian exchanges, cultural exchanges have political and ideological elements. West Germany wanted exchanges at the level of national culture to maintain the homogeneity of the people, but it was difficult to reach an agreement between the two sides because East Germany rejected "communist national culture" and tried to highlight its identity. However, after the signing of the cultural agreement, cultural exchanges were greatly expanded, and exchange visits by students, scholars, and artists, exchanges of literature and books, exchange of information on cultural heritage, and lending materials were relatively active. (https://www.dailynk.com//2019.4.5 Search)[2].

It is believed that cultural exchanges, which will end the era of confrontation and serve as the foundation for world peace and coexistence, should focus their capabilities on civilian-led exchanges that can be carried out consistently without being affected by the political interests of the South and the North. It is said that it is wise to consider the direction in which the public and private sectors can join after creating an atmosphere and trust through this. Chung Chang-yeon (Director of Hyundai Research Institute) "The path to transition to the Korean Peninsula in 2018, how should we open it? Need to establish multi-layered exchange and cooperation and trust in order to continue negotiations between the two Koreas and the U.S. (Chung, Chang-yeon, 2018)[3].

South and North Korea, still have had some partial views towards each other's culture due to the division of territory. The unification of national culture symbols, thus, should be made 'to contribute to the South and North Korean cultural integration based on national sentiment', 'to represent the integrated South and North', 'to include the universality which all the members consent to and the diversity which helps people to recognize each other's culture', 'to secure easy choice for unification and suitable actions' and 'to guarantee the structure of sustainable and everyday discussion'. South and North Korea will only then overcome the difference of the view towards each other and step forward more actively to unify the symbols.(Shin, Hyun-Wook, 2008)[4]

A sober recognition of this situation would suggest that the inter-Korean exchanges should be expanded both quantitatively and qualitatively based on the national sympathy of Korean people. In order that most Korean peoples are able to share a unification consciousness adjusted to the changing inter-Korean relationship, it is needed to actively develop and make full use of unification culture contents.(Jeon, Young-sun, 2006)[5]

In order to achieve more effective results, it is a cultural policy to maintain mutually beneficial relations between north and south Korea and to support them. The authors intend to argue for problems and solutions through consideration of the situation in which north and south Korean cultural exchanges are in place and policies to revitalize private exchanges and common cultural contents of the two Koreas are laid down. For this study, the researcher will compare and analyze the cultural contents performed together with the situation of North and South Korea based on academic thesis and newspaper articles on the unification study. Therefore, this study is intended to provide a basic data for developing mutually beneficial performance contents for sustainable inter-Korean performing arts exchange.

\section{Point}

\subsection{The Situation of Cultural Exchange between South and North and Korea}

Cultural exchanges between the two Koreas began in the 1990s after a period of intense ideological confrontation. Kim Dae-jung and Roh Moo-hyun administration efforts on the cultural exchanges were active, but this was impeded during the Park Geun-hye and Lee Myung-bak administration because of 
the environment and sustainability issues due to North Korea's nuclearization program. Moon Jae-in, which has no active exchange regime since the first inter-Korean summit and North America summit but the North's nuclear program and powerful North Korea of the United Nations that are associated. Normal exchanges under the sanctions have been difficult. However, inter-Korean consultations were actively held, and in 2017, the government encouraged various cultural exchanges such as culture, art, and academics. In 2017, North Korean officials were invited to the Gwangju Biennale, Korean traditional music festival, and Pyeongchang Winter Olympics. Unification Ministry's White Paper on Unification 2018 (Seoul: Unification Ministry, 2018)[6].

In this book, the authors examined the status of cultural exchange cooperation that has been going on since the time of active exchanges, and identify the issues and challenges which will be used as bases for the advancement of exchanges and cooperation in the future. For this study, it is necessary to compare and analyze the inter-Korean relations from the Kim Dae-jung government to the Moon Jae-In government and the performing arts contents that the South and the North have worked with.

\subsubsection{Kim Dae-jung and Roh Moo-hyun regime, (1998.2 2008.2)}

During Kim Dae-jung to Roh Moo-hyun administrations, there were a period of brisk cultural exchange between the two Koreas. This is the most prosperous in terms of inter-Korea relationship. There was a consistent policy for reconciliation and cooperation. Despite the strained surroundings of nuclear development, cultural exchange projects were carried out and the two Koreas paid much attention to easing tensions.

[Table 1] Representative inter-Korean cultural exchange cooperation projects (1998.2 2008.2)

\begin{tabular}{|c|c|}
\hline Period & Name of the event, venue, and contents \\
\hline 1998.5.2 5.12 & $\begin{array}{l}\text { Little Angels Pyongyang Performance - Folk Dance Tracks, Gayageum Byeongchang, Arirang, Gunbam } \\
\text { Taryeong, } \\
\text { Whistle (North Korean song) }\end{array}$ \\
\hline $1998.5 .29 \sim 6.11$ & South-North Joint Photo Exhibition (Pyongyang, Seoul Arts Center) \\
\hline 1998.11.3 11.5 & The 1st Yunsang Unification Concert (Pyongyang) - Swings, Sarangga, Gwangju, etc. \\
\hline 1999.12.15 & $\begin{array}{l}2000 \text { Peace and Friendship Concert - Roger Clinton and other North and South Korean artists - Separation, } \\
\text { Labyrinth of Love, Bong Seon-hwa, etc. }\end{array}$ \\
\hline 1999.12 .20 & $\begin{array}{l}\text { First National Unification Concert (Pyongyang)-Nice to meet you, from Seoul to Pyongyang, a million roses, } \\
\text { morning dews, the Tumen River with tears, spring maid, hand in hand. }\end{array}$ \\
\hline 2000.5.24 5.30 & $\begin{array}{l}\text { Pyongyang Student Boys and Art Troupe Seoul Performance - Baekdu's Hoofs, Hwiyang Niliri (music), Hide } \\
\text { (dance), Sound Seungjeongo (instrument) etc. }\end{array}$ \\
\hline 2000.5.29 6.11 & Pyongyang Art Troupe's Seoul Performance \\
\hline $2000.8 .18 \sim 8.24$ & South-North Symphony Orchestra Joint Concert (Seoul) - Thinking of Company, Bong Seon-hwa \\
\hline 2000.12.11 12.18 & Mount Kumgang Theater Company (Seoul) - Arirang, Bong Sun-hwa \\
\hline $2001,2002.4$ & Kim Yeon-ja "April Spring Art Festival" \\
\hline 2003.8.9. 8.12 & KBS Pyongyang Singing Contest \\
\hline 2003.8.29 & Daegu Summer Universiade South and North Korean Youth Joint Cultural Event (South Korea) \\
\hline 2003.9.21 9.26 & Youth Student Historic Site Survey (Visit) \\
\hline
\end{tabular}




\begin{tabular}{|c|c|}
\hline 2003.10.6 & $\begin{array}{l}\text { Unification Concert (Pyongyang)-Our wish is unification, and let's meet again (Joint performance by artists } \\
\text { from north and south Korea) }\end{array}$ \\
\hline 2003.10.23 10.27 & National Unification Peace and Sports Culture Festival (Jeju Island) \\
\hline 2003.11.20 11.22 & South-North Joint Senior Exhibition (Geumgangsan) \\
\hline 2004.4.9 6.20 & Goguryeo Cultural Exhibition (Seoul) \\
\hline 2004.6.14 6.20 & South-North Joint Photo Exhibition "My Country with Flowers" (Pyongyang) \\
\hline 2005.2 & $\begin{array}{l}\text { Formation of the Inter-Korean Joint Compilation Committee for the Great Dictionary of the Republic of } \\
\text { Korea }\end{array}$ \\
\hline 2006.3 & $\begin{array}{l}\text { South-North Joint Compilation Project Meeting of the Big Dictionary of the Korean People's Republic of } \\
\text { Korea until the fourth round of the meeting. }\end{array}$ \\
\hline 2005.6.14 6.17 & $\begin{array}{l}6.15 \text { Pyongyang University Festival, Cho Yong-pil Performing in Pyongyang, National Writers' Congress } \\
\text { (Pyongyang) }\end{array}$ \\
\hline 2006. 4.30 & Yoon E-Sang will be held at the Geumgangsan Cultural Center (Kumgangsan Mountain) \\
\hline $2006.6 \sim 10$ & Special Exhibition on National Treasure-grade Cultural Heritage in North Korea (Seoul and Daegu) \\
\hline 2006.10 .30 & 6.15 Established the Association of Korean Writers (North and South Korean Writers) \\
\hline 2007.9.3 11.9 & South-North Joint Excavation Survey of Manwoldae, Kaesong, 2005 Agreed 2005 \\
\hline
\end{tabular}

\subsubsection{Lee Myung-bak and Park Geun-hye regime. (2008.2 2017.3)}

In 2008, Lee Myung-bak government, a denuclearization and openness policy based on the ambitious Vision 3000 project was implemented in conjunction, but new. The exchange and cooperation project almost ceased to ensue. The existing projects were faced with a tense situation along with the exchange of political, social and economic sectors due to the attack on Mount Kumgang, nuclear development, Cheonan and Yeonpyeong Island. However, in the second half of 2011, the government resumed select exchanges in the fields of culture and arts and religion, excluding non-political and military sectors. In response to North Korea's sinking of the South Korean warship Cheonan on March 26, 2010, the government's key move is to block all aid from the Kaesong Industrial Complex and Mount Kumgang, inter-Korean trade suspension, new investment ban, North Korean ships' operations in South Korea, and humanitarian aid. According to the measure, no matter how humanitarian the North is, it is impossible to provide aid to the North unless it consults with the South Korean government in advance. (5.24 Action, Korea Economic Terminology Dictionary)[7].

Despite the 5.24 policy that continued in Park Guen-hye's administration, the North Korean nuclear and missile development continued thus causing tension between North and South Korea, North America. Cultural exchanges were almost halted.

[Table 2] Major cultural exchanges and cooperation between the two Koreas (2008.2 2017.3)

\begin{tabular}{|l|l|}
\hline Period & \multicolumn{1}{c|}{ Name of the event, venue, and contents } \\
\hline $2008 \sim 2010$ & $\begin{array}{l}\text { The 3.4th (Gaesong)-2010 Inter-Korean Joint Excavation Survey of Manwoldae in Kaesong was } \\
\text { suspended }\end{array}$ \\
\hline & $\begin{array}{l}6.15 \text { "Unification Literature" by the Association of Korean Writers (North and South Korean Writers) } \\
\text { published until 2008 and discontinued after publication of the second edition. }\end{array}$ \\
\hline
\end{tabular}


A Study on the Cultural Exchange between South and North Korea in the Unification Era with Focus on Performance Arts as Cultural Content

\begin{tabular}{|c|c|}
\hline 2011.11.14 & An emergency restoration survey on the joint excavation of Manwoldae in Kaesong (Gaesong) \\
\hline 2012. 2. 28 3.3 & Chung Myung-hoon visits North Korea to rehearse with the Milky Way Orchestra. \\
\hline 2012.3.14 & $\begin{array}{l}\text { North Korea's Milky Way Orchestra and Radio France Philharmonic perform together } \\
\text { Conducted by Chung Myung-hoon (Paris, France) - Concerto by Saint-Saint's, Nilignia, Brahms } \\
\text { Symphony, Arirang }\end{array}$ \\
\hline 2012.3.21 & $\begin{array}{l}\text { Discussion on the issue of the joint recovery of the looted cultural assets of the Jogye Order Central New } \\
\text { Society (Personality) }\end{array}$ \\
\hline 2012..6.13 7.22 & Landscape Inter-Korean Land Exhibition (Goyang Nuri) \\
\hline 2012. 10.10 10.12 & North Korean movie Comrade Kim flies to the sky Special screening \\
\hline 2012.11.8. 11.12 & Special screening of the Gwangju International Film Festival (Original: Arirang) in Pyongyang \\
\hline 2012.11.13. 17 & Ahn Jung-geun's Memorial Project - Sincheon-gun, Hwanghae Province \\
\hline
\end{tabular}

\subsubsection{Moon Jae-in regime (2017.5 )}

Lee Myung-bak, Park Geun-hye of inter-Korean relations are a time of the regime but can do. North Korea's nuclear, missile development and strained atmosphere have also had a significant impact on inter-Korean cultural exchange and cooperation projects. However, despite the tense inter-Korean atmosphere, inter-Korean dialogue, which took place in the wake of the 2017 Pyeongchang Olympics, led to inter-Korean summits and North Korea-U.S. summits, and cultural exchange projects, which are not subject to sanctions, began to become more active.

[Table 3] Major cultural exchange cooperation between the two Koreas (2017.5 )

\begin{tabular}{|l|l|}
\hline Period & Name of the event, venue, and contents \\
\hline 2018.2 .8 & Samjiyon Orchestra (Pyeongchang Winter Olympics, Special Performance to Wish Paralympic Games) \\
\hline 2018.2 .11 & $\begin{array}{l}\text { Samjiyon Orchestra (Pyeongchang Winter Olympics, Paralympic Games Special Performance) Seoul- } \\
\text { Nice to meet you, our wish is unification, Baekdaek and Halla are my country, Arirang, J's equivalent, } \\
\text { Osole mio and other world folk songs. }\end{array}$ \\
\hline $2018.3 .5 \sim 3.6$ & $\begin{array}{l}\text { South Korean art troupe performances (spring is coming) and our wishes are to meet again (joint } \\
\text { performances by South and North Korean art troupes. }\end{array}$ \\
\hline $2018.718 \sim 7.22$ & Invited screenings of nine North Korean films at the 22nd Bucheon Fantastic Film Festival \\
\hline $2018.9 .7 . \sim 11.11$ & 2018 Gwangju Biennale (North Korean Art Exhibition) \\
\hline $2018.11 .8 . ~ 11.14$ & Korea National University of Arts Festival (North Korean oil paintings) Seoul \\
\hline
\end{tabular}

\subsection{Contents of inter-Korean cultural exchanges (performance arts)}

Inter-Korean cultural exchanges were based on the principle of mutual benefit, and if the mutual exchange performance under these basic principles played an important role in improving inter-Korean relations, it would have been a catalyst for the inter-Korean summit. ( Ministry of Culture, Sports and Tourism, 2013)[8].

Performances, which are also used as indicators of inter-Korean relations, were not only broadcasted through broadcasting media, but were also of great interest to the public. As a result of online reservation 
site Interpark 24-hour ticket application for Samjiyon Orchestra's special performance (Gangneung /Seoul) from noon on the 2nd to noon today, a total of 117,123 people participated in the Seoul performance and 39,109 participated in the Gangneung performance. A total of 156,232 people applied, proving their high interest in the Samjiyon Orchestra's special performance. A total of 530 (250 in Seoul and 280 in Gangneung) was given a total of 1,060 tickets, two each, through a random draw by age group. The final competition rate was 468:1 in Seoul and 140:1 in Gangneung. (https://www.nocutnews.co.kr/news/4917742/2019.4.11.search)[9]. The content used to organize the performance was also a hot topic. The picture below is a poster for the performance of the Samjiyeon Orchestra in February 2018 praying for the success of the PyeongChang Winter Olympics.

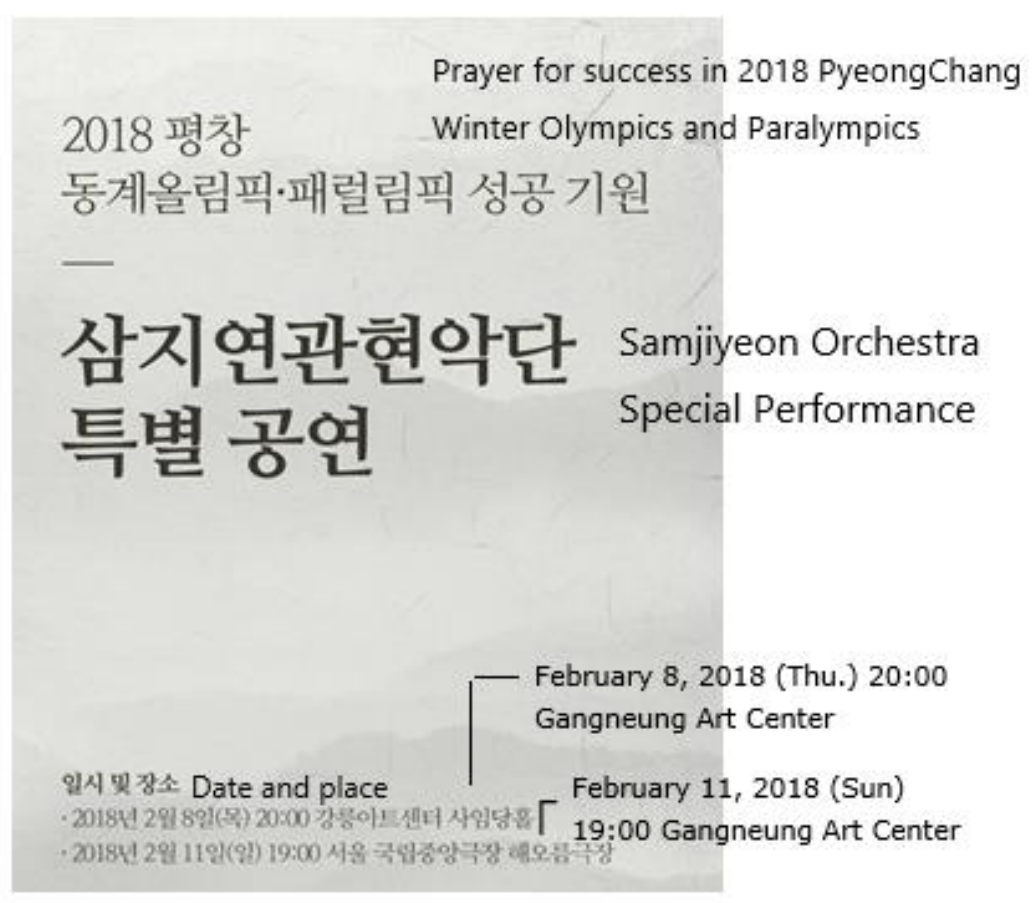

[Fig. 2] A total of 156,232 people participated in the ticket application for the Samjiyeon Orchestra's special performance. (Photo $=$ Provided by Interpark

In addition to "Arirang," "Nice to meet you," "Our Wish," and "Let's Meet Again," Korean folk songs and North Korean pop songs "Whistle," our "Tearful Tumen River," "Labyrinth of Love" and "Dear J." were performed.

\subsubsection{Features of Content}

The characteristic of north and south Korean exchange performances is that they are performed mainly on political issues and content that does not pose a threat to each other's stay. Both South and North Korea go through pre-performance consultations. When South Korean performers perform or hold joint performances in North Korea, it prefers content that is not harmful to North Korea's stay. It is also performed under the principle of mutual benefit in the South Korean performance.

The inter-Korean cultural performance exchange is a large-scale project that moves performing artists, stage installation, and performing artists' joint performances require North Korea to use traditional instruments to overcome differences in singing styles and performances.

Therefore, there are many difficulties, and these points have been solved by working together with 
A Study on the Cultural Exchange between South and North Korea in the Unification Era

with Focus on Performance Arts as Cultural Content

interactive content.

\subsubsection{Content commonly used by the South and the North}

Arirang, a traditional Korean folk song that means 'pleasure in visiting me', is the most frequently used content in the two Koreas' joint performances.

This is because people of the two Koreas, who are rooted in this land, know the song through oral or educational methods. The Korean people's spirit is embodied in its content. In addition, many other traditional folk songs were used as major content such as "Our Wish," which sings unification and unity, "Bongseonhwa," which contains the historical nature of anti-Japanese, and "Nice to meet you" of North Korea.

The contents of these performances combines the heterogeneity of ideas between the two Koreas with the materials contained in the common emotional denominator of the Korean people towards the direction of unification, the ultimate goal of these undertakings.

\subsubsection{Problems and development measures}

1) Limitations:

The reciprocal visit South Korean government, from Kim Dae-jung to present, generally use the same content in the exchanges. This is because it is carried out vis-a-vis the political ideology of both countries. But isn't it all because it has a strong sense of purpose as a political event? Isn't it because it's a one-time performance that require a political influence or effect in the two Koreas? The narrowmindedness that similar contents are performed in each episode is not suitable for the nature of art in pursuit of diversity and progress, and it is expected that the expansion of performance art exchanges will reduce interest and public effects.

It is necessary to overcome various heterogeneity such as performance style and instruments used. North Korea has developed and developed various Korean traditional music instruments in orchestras, and this is a difficult part of the ensemble with the arrangement of the songs.

For example Eunhasu Orchestra played with the entire-mixed orchestration, and showed a performance technique that makes the western music instruments in the traditional music sounds not at all awkward. Also Chosun People's Military Ensemble displayed the entire-mixed orchestration, but different from that of Eunhasu Orchestra in the positions of the traditional music instruments. Besides this mix, at the concert of Chosun People's Military Ensemble, there were small traditional orchestration and the part-mixed orchestration. Both of them expressed the harmony with accordion, and combined the traditional bamboo musical instruments with harmonica presenting the harmony and the ethnic taste. Lastly, the electrical music band, Moranbong band is presenting the ethnic, traditional sentiment through the folk song scale in the songs, which are also minyo(folksong)-style song with the electrical instruments, and also presenting through adding the kwaenggwari with other electrical music instruments. In North Korea, the music groups are pursuing the mixed-orchestration to achieve the traditional form, the modern sense of beauty, and the popularity at the same time, but it can be told as a way of presenting the harmony in traditional music. The traditional form, modern sense of beauty, and the popularity seem as though they will be pursuing the mixed orchestration continuously for the harmony, engaging with the North Korean Government's political intentions. ( Bae, Ihngyo, 2010)[10].

2) Solution:

In order to overcome the limitations of the above problems, there is a need to establish an organization that can discuss on the inter-Korean culture and performance arts exclusively. It is necessary to proceed with negotiations and policies by dividing them into social and cultural exchanges in the inter-Korean exchange project and to divide them into future-oriented subdivisions in the field of performing arts and content development in the field of society and culture. 
The concept of philosophy that recognizes the nature and existence of altruistic self and other objects in the co-development of new content and the heterogeneity of each other are discovered during the performance exchanges through these consultative bodies. The difference between altruism and tolerance is that tolerance allows me to walk on the road and move quickly by avoiding others to one side when they come at a faster pace, and altruism is the basic concept of a harmonious city and society by yielding and cooperating with each other. To this end, first, there is a need to establish a consultative body that allows the South and North to jointly develop cultural contents in the near future, as well as to establish an organization to research this field professionally. Here, not only the development of common cultural contents to overcome the limitations, but also the development of future-oriented interKorean cultural and artistic performance contents should be studied while looking forward to a unified motherland.

It will be necessary to develop a system to realize the objective of the exchanges. In addition, the two Koreas should not rush to produce ostentatious results, but should create policy organizations and create future-oriented new performance culture and art contents in accordance with the principle of mutual benefit.

\section{Conclusion}

In 2018, the Korean Peninsula had a time of upheaval. It was marked with the North Korea's nuclear and missile development, strong U.N. and U.S. sanctions, a meeting between the leaders of the two Koreas to resolve it, and a historic meeting between the leaders of North Korea and the U.S.

People around the world dreamed of unification in the era of inter-Korean harmony, and this hope is coming true. It was the cultural and artistic exchange project that played a major role in creating this atmosphere, and among them, the performing arts sector implied its symbolism and drew great attention among the residents of the two Koreas.

Culture refers to the people's way of life. Even if people from the two Koreas use the same language as Koreans, they have not had mutual exchanges for a certain period or have lived toward different political ideologies and various patterns of life. Here, we can see that there is a significant heterogeneity. This was learned through the examination of the cultural and artistic exchange. In order to overcome this heterogeneity and prepare for the unification era, we need more active exchanges between the two Koreas, and we need to find and develop content that needs to be used and developed together beyond just exchanges. In addition, it is necessary to establish an altruistic relationship between the two Koreas to understand and get to know each other, the North and the south Korea should collaboratively study and develop content for the exchanges.

Through this study, there was a review of the heterogeneity of the cultures of North and South Korea. The results obtained through the comparative analysis of the performance contents of the two South and North Koreas can be found in the difference between the current system of the two Koreas and the perspective of thinking consciousness. However, in the joint cultural and artistic performances between the two Koreas, it was possible to see how they could help each other understand through the performances of common cultural contents between the two Koreas, and it made us feel the necessity for the development of cultural contents developed ahead of the unification era. To this end, it is necessary to conduct sustainable research with the establishment of an organization for joint development of cultural and art contents between the two Koreas. In addition, there should be full support from the North and the South for cultural and art content projects for the future of a unified country.

The development of content that can be shared beyond the exchange of exhibitionistic culture and arts to create a temporary atmosphere will play a major role in bringing about the emergence of the Korean people in the era of unification under the principle of mutual benefit between the North and the 


\section{South Korea.}

In the meantime, there is a regret that there are limitations in the joint performing arts and research data on it. This study on the contents of cultural and performing arts of the North and the South is hoped to serve as an opportunity for other researchers to conduct additional studies.

Even if this study has not achieved satisfactory results due to its limited coverage, it could create an impact on research related to inter-Korean culture.

\section{References}

[1] http://www.ksw-news.com/news/articleView.html?idxno=3837, Apr 2 (2019)

[2] https://www.dailynk.com, Apr 5 (2019)

[3] Chung Chang-Yeon, How should we open the way to change the Korean Peninsula in 2018? - Need to establish multilayered exchange and cooperation and trust in order to continue inter-Korean and North Korea-U.S. negotiations, Nationalization, (2018), Vol.91, pp.19-21.

[4] Hyun-Wook Shin, Direction in the Unification of National Cultural Symbols of South and North Korea, Culcure Art Contents, (2008), Vol.1, No.1, pp.285-316.

[5] Young-Sun Jeon, The Necessities and Directions of Developing Unification Culture Contents in Korea, The Review of Korean Cultural Studies, (2006), Vol.18,No.18, pp.23-47

[6] Unification White Paper 2018, Unification Ministry, (2018), p.72.

[7] https://dic.hankyung.com/economy/view/?seq=12249, Apr 1 (2019)

[8] Young-Jung Park, Yang-Yeol Oh, Seeong-Su Kim, Joon-Young Shin, Hee-Seop Jeong, Ministry of Culture, Sports and Tourism, Analysis and Development of Inter-Korean Cultural Exchange Cooperation Projects, (2013), Vol.1, p.40.

[9] https://www.nocutnews.co.kr/news/4917742, (2019)

[10] Ihn-Gyo Bae, The aspect of orchestrating the traditional instruments in North Korean Capital music organizations in 2010s, National Gugak Center, (2015), No.31, pp.43-66. 